\title{
A Quantitative Analysis for the Correlation Between Corporate Financial and Social Performance
}

\author{
https://doi.org/10.3991/ijes.v4i4.6551 \\ Wafaa Salah and Mostafa A. Salama \\ The British University in Egypt (BUE), Cairo, Egypt
}

\begin{abstract}
Recently, the corporate social performance (CSP) is not less important than the corporate financial performance (CFP). Debate still exists about the nature of the relationship between the CSP and CFP, whether it is a positive, negative or a neutral correlation. The objective of this study is to explore the relationship between corporate social responsibility (CSR) reports and CFP. The study uses the accounting-based and market-based quantitative measures to quantify the financial performance of seven organizations listed on the Egyptian Stock Exchange in 2007-2014. Then uses the information retrieval technologies to quantify the contribution of each of the three dimensions of the corporate social responsibility report (environmental, social and economic). Finally, the correlation between these two sets of variables is viewed together in a model to detect the correlations between them. This model is applied on seven firms that generate social responsibility reports. The results show a positive correlation between the Earnings per share (market-based measure) and the economical dimension in the CSR report. On the other hand, total assets and property, plant and equipment (accounting-based measure) are positively correlated to the environmental and social dimensions of the CSR reports. While there is not any significant relationship between ROA, ROE, Operating income and corporate social responsibility. This study contributes to the literature by providing more clarification of the relationship between CFP and the isolated CSR activities in a developing country.
\end{abstract}

Index Terms-Financial performance; Social performance; Machine learning.

\section{INTRODUCTION}

Nowadays, society practices more pressure on organizations to become more socially responsible. This results in increasing the number of organizations that start to give more importance to environmental and social disclosure (Karagiorgos, 2010) [1], along with achieving their financial goals. Organizations increase their CSR activities to improve their reputation and their company image. In return, organizations affect customer loyalty, increase sales and meet stakeholders obligations (Oh, W. and Park, S., 2015) [22]. Although CSR activities are costly, but they generate cash flows and a reputation that covers the associated costs. Socially responsible organizations have fewer risks of negative social events, bribery, paying fines for pollution and negative advertisement which cause damage to their reputation (Ozcelik et al.) [4]. KPMG International's survey (2013) [2] reports a dramatic increase in corporate social reporting rates in the last two years. Almost 76 percent of firms in USA now report on CSR, 73 percent in Europe and 71 percent in Asia Pacific. Market transparency and sustainable products are parts of the social responsibility that attract more investors.

Corporate social responsibility (CSR) is the commitment of a business to consider social, economic and environmental requirements [5]. Corporate social Performance (CSP) is the concerns, actions, and reputations that reflect the underlying values and behaviors of CSR. There are several debates about CSR, the first debate lies on whether it provides an addition or not to the firms' financial performance [6]. Some literature argues that CSR is costly without any benefit (Brammer et al., 2005; Lopez et al., 2007 and Jalal,

2009) [7], [8], [9]. However, others argue that CSR improve firms financial performance (Branco and Rodrigues, 2007; Burhan and Rahmanti, 2012) [10], [11]. The second debate that firms must have a good financial performance before having CSR program as CSR is costly. While others argue that CSR is a long term investment activities so CSR is a before profit (Santoso, A. and Feliana, Y., 2014) [47]. CSR reporting is unenforceable and practised on a voluntary basis. This is why it is important to investigate whether CSR reporting practices increase firms' financial performance or the enhanced financial performance improves their social disclosure. Is it worthwhile for organizations to be socially responsible? According to Beurden and Gossling (2008) [13], the answer to this question has not yet been found. Organizations are more likely to invest in environmental and social behavior if they believe that these investments enhance their financial results. Alternatively, the lack of a positive relationship between CSP and CFP is likely to weaken firms' efforts and hold back progress toward socially responsible organizations (Cordeiro,J. and Tewari, M. , 2015) [14].

The objective of this study is to investigate previous question and try to find answers. There is a substantial body of literature that investigates the relationship between CSR and CSP using different measurement methods. CSP can be based on accounting-based and marketbased measures [15]. Market-based measures include the stock performance, earning per share, share price appreciation, while accountingbased measures include profitability measures, asset utilization, return on assets and asset turnover (Rockmore,B. and Jones,F.,1996) [16]. This study takes place on the nature of the relationship between the CSR and CFP. It measures financial performance by both accounting-based measures (ROA, ROE, total asset, PPE and operating income) and market-based measures 
PAPER

A Quantitative Analysis for the Correlation Between Corporate Financial and Social Performance

(Earning per Share). The firms used in this study were listed on the Egyptian Stock Exchange and their performances were measured between 2007 and 2014 using annual financial reports, covering the total of eight years. The CSR measures were collected from firms' sustainability reports that were prepared according to GRI (Global Reporting Initiative) and ISO 26000 Index. This study uses annual reports for collecting CSR data for organizations that have no standalone CSR report. In order to analyze the relationship, a model was designed to quantitatively discover the correlation between Social responsibility and financial performance of firms. This model extracts the different accounting and market based measures of a firm across successive years. Market-based measures include price per share while Accounting-based measures include profitability measures, asset utilization, return on asset and asset turnover. The rest of this paper is organized as follows: Section II presents the literature review on the analysis of CSR and the investigation on the correlation between CSR and CFP. Section III describe the CSR and CFP analysis methodology. The results and discussion appear in section IV and finally the conclusion is in section $\mathrm{V}$.

\section{LITERATURE REVIEW}

A growing body of empirical research has focused on CSR disclosure issues in developed countries. Very few studies are available on the CSR disclosure practices in developing countries in general and in Arab countries in particular and this requires studying CSR issues in Egyptian society (Hanafi, 2006) [17]. CSR is based on the notion that businesses have social and environmental obligations besides the economical one. CSR reporting starts in the

1880s where firms were reporting their social activities. In the 1990s, the CSR reporting was improved to include social, economical and environmental activities (Chiong, 2010) [18]. There has been a remarkable discussion over the last two decades among scholars and practitioners on an agreed upon definition of CSR, but the most critical point is that the majority of these definitions mention four different areas of responsibilities; legal responsibility to the government, economical responsibility to the investors, social and environmental responsibilities to the community. Carroll (1991) [19] classified CSR into four areas of firm responsibilities economic, legal, ethical and philanthropic. Maignan and Ferrell (2004) define CSR as an important management activities that contribute to society and stakeholders social welfare. Crowther and Aras (2008) describe CSR as what should be the relationship between firms, governments of countries and individual citizens. Vitezic et al. (2012) [20] mention that CSR is when a firm try to balance between its social, economic and environmental activities and its stakeholder's economic welfare. Social responsibility is considered an essential factor in management strategy (Song, C., and W. Oh. 2015) [21]. Oh,W. and Park,S.(2015) describe CSR as a corporate management [22].

\section{A. Measuring Corporate Social Performance}

The measures that represent firms' financial performance are clear and precise as Return on Assets, Return on Equity and Return on Investment. The measures that represent firms' social performance are not that clear because of its qualitative nature. Common CSP include, for example, Labor Practices and Decent Work, Human Rights and Environmental Protection System (Chen, C. and Dalen, J., 2010). The most common methods used in literature for quantifying CSP are content analysis of annual reports, Questionnaire surveys, Reputational measures, Onedimensional indicators and Ethical rating(Soana ,M.,2011). Research takes place on the nature of the relationship between the CSR and CFP. The literature review [23] investigates the different factors that evaluate this relation as positive, negative or nosignificant relation. This review concluded that this relation is a positive relation, and it is influenced by size of the firm as an important confounding factor. The measurement of corporate social performance is quantified based on different measures. Five measures, as listed in [24], are investigated in different researches. Four of these measures are as follows: (1) Providing survey questionnaires to managers and directors, then analyzing the responses by researchers. (2) Monitor the firm reputation perceived by third party that is not biased by the firm's financial performance. (3) Performing a dialog with the local community concerning the environmental/social/legal practices of the firm. (4) Calculating the ethical rating of the firm by specialized agencies. These four measures include the interference of a third expert party to evaluate the results/outcome of Survey, reputation and dialog methods or directly calculating of the ethical rating. These third party dependent measures varies according to the nature/background of the third party, the used quantification methods and the different used sources for each measures. Finally, the fifth measure is the content analysis that is based on information retrieval methods. This measure consists of counting words, lines or sentences regarding the social information. The content analysis (CA) is a measure that presuppose that the social disclosure or the CSR report is a good reflection of the actual CSP. The CA based on quantity is based on counting the number of characters, words, sentences, pages, proportion of pages in a specific category. The work in [25] counts the number of statements per each category, and correlate between these numbers (e.g. Environment, Community, Energy, and Human resources) and some accounting measures (e.g. Return on assets, Return on equity). Assumptions like in [26] stated that the quantity of a specific category within the disclosures reveals the importance of that category. The debate around CA lies on whether the quantity of relevant text detected is sufficient or the semantic quality is still required [27]. In other words, CA may not assess the intensity of the Social performance activity.

\section{B. Relation between corporate social performance and financial performances}

Several studies tried to explore whether CSP disclosure improves financial performance, destroys it or has no value at all. CSP can be viewed as an extension of firms' efforts to promote effective corporate governance, ensuring organizations' sustainability through sound business practices that promote accountability and transparency toward the society as a whole (Jo, H. and Harjoto, M.a., 2012) [28]. Abduallah, A. (2003) [29] has analyzed the objectives and importance of voluntary disclosures to decision-makers in the Egyptian market. He also analyzed the economic consequences of it. The study found evidence that support the importance of the voluntary disclosure. AlKhial (2009) [30] tried to recognize the im- 
PAPER

A Quantitative Analysis for the Correlation Between Corporate Financial and Social Performance

portance of voluntary disclosure and identify the most important information that should be included in the financial reports. The study found that voluntary disclosure affects firm investment decisions and reduces the cost of capital and information asymmetry. Hussainey, K., Elsayed, M. and AbdelRazik, M.(2011) [31] use a sample of 111

Egyptian listed companies for the period of 2005-2010. They found that $66 \%$ of the Egyptian listed companies disclose on average 10-50 CSR statements and the product/customer information is used extensively compared with other types of CSR information.

The relationship between CSR and organization financial performance attracted the attention of academics and managers and was empirically examined by several studies with different measurements. However, despite a large number of studies that have addressed this issue, their results are conflicting (Ambec and Lanoie, 2008) [32]. Although there are some empirical studies that support a positive relationship between CSP and CFP, a large number of studies find mixed and even negative evidence of this link. Therefore, results from archival research seem to suggest that CSP can add value to the firms only under certain conditions (Barnett and Salomon, 2006 [33]; Servaes and Tamayo, 2013 [34]). There is a call for deeper understanding of the mechanisms linking certain CSR efforts to certain performance outcomes (Perrini, Russo, Tencati and Vurro, 2011). Based on existing literature findings, the relationship between CSP and CFP can be classified into negative, positive or mixed relationships between them.

Most studies found a positive relationship between CSP and CFP (Griffin and Mahon, 1997; Hayibor, and Agle, 1999). Endrikat, Guenther and Hoppe (2014) [36], conducted a meta-analysis and the results indicate that there is a positive and partially bidirectional relationship between CSP and CFP. The findings of the study suggest that the relationship is stronger when the strategic approach underlying CSP is proactive rather than reactive. Dumitrescu and Simionescu (2014) [40] test the sign of the relation between CSP and CFP empirically. The results indicate a positive and significant relationship, supporting the view that responsible financial performance can be associated with a series of bottom-line benefits. Hassan and Melegy(2014) [41] found that the content of voluntary disclosure provided by companies in both annual reports and web sites has economic value, to some extent, and it is important for investors. Ozcelick, Ozturk and Gursakal, 2014) state three perspectives on the relationship between CSP and financial performance: First, researchers argue that financial benefits exceed the costs of investment for CSR because the investment in CSR involves benefits as enhanced employee, enhance relations with investors and government. Second, Investment in CSR generates positive financial benefits by managing stakeholder. Finally, organizations investing in CSR have predominant resources.

Different studies suggest that CSR activities can contribute to improve the relationship of the organization with stakeholders, influencing financial performance positively (Orlitzky et al., 2003 [38]; McWilliams et al., 2006 [39]; Barnett

2007 [42]; Lee 2008 [43]; Bhattacharya et al., 2009 [37]). However, other studies found that good CFP leads to good CSP as the more the profitable the firm, the more the resources directed to socially responsible activities. According to the slack resource theory, the availability of resources was an important factor for the firm to do CSR (Santoso,A. and Feliana,Y., 2014) [47]. The studies that found a negative relationship between CSP and CSF are not found often. Most researchers investigate the effect of organizations financial condition on investing in corporate social activities. Organizations having extra resources have bigger possibility to invest in environmental and social activities and report their CSR (Parket and Eilbirt, 1975) [45]. Researchers have hypothesized that there is a negative relationship between CSR and CFP because of high costs of CSR activities which lead to decline in organizations profits (Oh and Park, 2015). Investing in CSR involves additional costs such as improved employee conditions, adoption of environmentally friendly practices, charitable donations etc. Organizations socially responsible have higher costs than organizations that have less or no social responsibility (Barnett 2007[42]; Scherer and Palazzo 2011 [46]). Several studies argue that there is a negative relationship between earnings per share and CSR (Brammer et al. 2005 [7]; Lopez et al. 2007 [8]). Some studies argue that CSR is an after profit activities as spending on CSR activities is costly while providing no financial return. Other studies argued that CSR is a before profit program as it is a long term investment activities (Santoso and Feliana, 2014) [47].

Although some studies found a positive or negative relationship between CSP and CFP, but other studies show an insignificant relationship between them. Hassan, et al (2009) [48] found that mandatory disclosure in Egyptian market has a highly significant but negative relationship with firm value, while the voluntary disclosure has a positive but insignificant association with firm value. Several studies didn't find any significant relationship between CSP and CFP (Brine et al., 2007 [?]; Fauzi et al., 2007 [49]; Aras et al., 2010 [50]; Ducassy, 2013 [52]). Nilipour and Nilipour (2012) [51] carried a study on the cement companies registered at Tehran Stock Exchange from 2007 and 2011. They found no relationship between financial performance and corporate sustainability performance.

Most of these researches lack investigating the correlation between different components of CSR report (Economic, Social and Environmental) and CFP. This Study breakdown CSR into three categories, then test the correlation between each category and CFP

\section{CSR AND CFP ANALysis Methodology}

A growing body of empirical research has focused on CSR disclosure issues in developed countries. Very few studies are available on the CSR disclosure practices in developing countries in general and in Arab countries in particular and this requires studying CSR issues in Egyptian society (Hanafi, 2006) [17]. CSR is based on the notion that businesses have social and environmental obligations besides the economical one. CSR reporting starts in the Financial data was sourced from the annual reports published by the different firms listed in the Egyptian stock exchange from 2007 to 2014. The sampled firms was selected based on those who provided standalone CSR report or annual reports for each year. Consequently, there are 42 annual reports that has been analyzed in this study. This data is processed to calculate the differ- 
ent ratios used in this research, and also remove the missing or incorrect records. Although the CSR reports may not describe exactly the social performance activity, it reflects a snapshot about the mindset of the firm's management [53]. Accordingly, the target of this work is to analyze the CSR report of a firm and extracts a quantitative measure that represents the CSP of the firm. The measure to be used here is the content Analysis CA measure of the CSR report.

The proposed CA methods is dependent mainly on Global standards of the CSR reports to ensure the quality of the measure rather than the quantity. The quality of the CSR reports is dependent on following the Global Reporting Initiative (GRI) G4 and ISO 26000 sustainability reporting standards. These standards are categorized into three main sections, the Economical, Environmental and Social dimensions. Each dimension is consists of list of instructions and guidlines to the informations that should be covered in the CSR report. The following points are samples of the information that used in our research.

\section{Social}

- Total number and rates of new employee hires and employee turnover by age group, gender and region.

- Ratio of basic salary and remuneration of women to men by employee category, by significant locations of operation.

- Percentage of new suppliers that were screened using human rights criteria.

- Total number of substantiated complaints regarding breaches of customer privacy and losses of customer data.

\section{Environmental}

- Energy consumption within the organization.

- Percentage of materials used that are recycled input materials.

- Monetary value of significant fines and total number of non-monetary sanctions for noncompliance with environmental laws and regulations.

- Emissions of ozone-depleting substances (ODS).

\section{Economic}

- Ratios of standard entry level wage by gender compared to local minimum wage at significant locations of operation.

- Development and impact of infrastructure investments and services supported.

- Proportion of spending on local suppliers at significant locations of operation.

The proposed model considers each dimension as a query document, then the correlation between this query and the target CSR report is measured. The degree of matching of each statement to the query sentence is measured by the number of common words in both sentence. This step is applied on the CSR reports gathered across a sequence of years from 2008 to 2014 . The relevance of the CSR report to the social, environmental and economical dimensions is measured for every year. According to the availability of the CSR reports for a firm, the extracted data set contains a series of three values for each CSR dimension.

The variation of values across a series of years is detected from both sets of CSP and CFP measures. Then the matching of increase/decrease in the values is captured to discover the dependent measures/factors from both sides. In the experimental part, Earning per share in the CFP measures is matched to the Economical dimension in the CSR reports. Also, total assets and property, plant and equipment in the CFP measures is matched to the Enviromental and Social dimensions in the CSR reports.

\section{RESULTS AND DisCUSSION}

The values of the financial and social measures are normalized to the range between 0 and 1 . The normalization process is applied to be able to compare between the values of both kinds of measures. Several measures like ROA, ROE, net income, operating income, PPE, EPS and total assets are examined. The ROA, ROE, net income, EPS and operating income represent the financial performance of the firm. While, the PPE and total assets represent the firm size. The measures that shows a high correlation to the CSR reports components are those related to the firm size as represented by PPE and total assets. Also the measures related to the financial performance as represented by EPS show a correlation to a CSR reports component different from those related to the firm size. Table I shows the correlation cofficient between these selected measures which shows a high correlation to the different components of the CSR reports.

TABLE I.

CORRELATION COEFFICIENT

\begin{tabular}{|l|c|c|c|c|c|}
\hline \multicolumn{1}{|c|}{ Firm } & $\begin{array}{c}\text { T. Asset } \\
\text { Environ. }\end{array}$ & $\begin{array}{c}\text { T. Asset } \\
\text { Social }\end{array}$ & $\begin{array}{c}\text { PPE } \\
\text { Environ. }\end{array}$ & $\begin{array}{c}\text { PPE } \\
\text { Social }\end{array}$ & $\begin{array}{c}\text { EPS } \\
\text { Econom. }\end{array}$ \\
\hline Tourism & -0.70 & 0.06 & -0.89 & 0.38 & 0.81 \\
Raya & -0.55 & -0.86 & -0.72 & -0.89 & 0.65 \\
Talaat & 0.51 & 0.50 & -0.50 & -0.49 & 1 \\
Mobinil & 0.73 & 0.71 & 0.22 & 0.35 & -0.98 \\
Kuwait & 0.51 & 0.07 & 0.41 & -0.31 & 0.72 \\
Auto & 0.41 & 0.82 & 0.50 & 0.84 & 0.68 \\
Glaxy & 0.65 & 0.54 & 0.73 & 0.66 & 0.35 \\
\hline
\end{tabular}

\section{A. Firm Size}

For each year from 2007 to 2014, the correlation coefficient showed a significant positive relationship between the firm total assets and the environmental and social dimensions in the CSR report. While a mixed correlation between total assets and the Economic dimension. The correlation coefficient between the total assets and Environmental dimension ranged from 0.414 to 0.730 , and between the total assets and Social dimension ranged from 0.54 to 0.820 . On the other hand, Chi-square test is applied to select the measures that show a high correlation to each of the components of the CSR report. The total assets measure is selected as the highest correlated feature to the Environmental and social dimensions. This means that firms which have greater assets will provide more comprehensive disclosure in the CSR report, especially in the Environmental and Social dimensions. Also, the correlation coefficient between the firms PPE and the Environmental and social dimensions in the CSR report showed a significant positive relationship. The correlation coefficient between the PPE and Environmental dimension ranged from 0.411 to 0.736 , and between the PPE and Social dimension ranged from 0.353 to 0.848 . The Chisquare test results show that the PPE measure is second higly correlated measure to the Environmental and social dimensions after the total assets measure. This result seems to support the literature review where firm size 
plays a significant role in satisfying the societies environmental and social needs. Figures 1 and 2 show a visualization of the correlation between the Social and Environmental dimensions of the CSR reports and the total assets and PPE measures. The positive correlation appears clearly in all years in firms like Kuwait, GP Auto and Glaxy. While this correlation appears partially in firms like Toursims, Raya and Talaat Mostafa especially in years 2013 and 2014.

\section{B. Firm Financial Performance}

Among years from 2007 to 2014, most of the firms shows a positive relationship between the EPS of the firm and the economical dimension in the CSR report. The correlation coefficient between the EPS and the economical dimension ranges from 0.65 and 1 in $75 \%$ of these firms. Figures 3 and 4 show the visual correlation between Earning per share (EPS) and Economical dimension in the CSR report for these firms. This result shows that the prosperity of the financial situation of the firm is clearly reflected in the economical information mentioned in the CSR report.

\section{CONCLUSION}

The results of this study appears to be logic and concurrent with the previous literature reviews. This study is Tourism

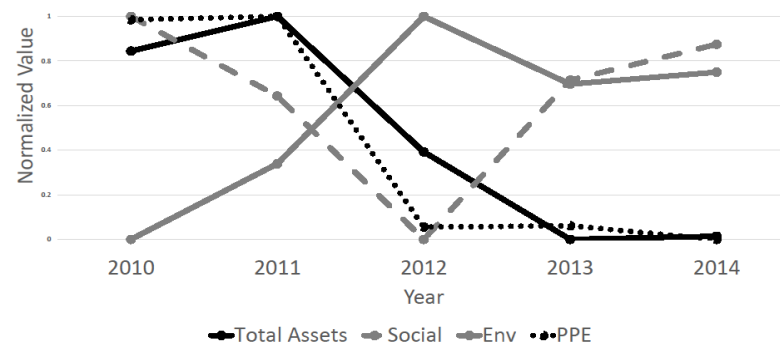

(a) Toursims

Raya

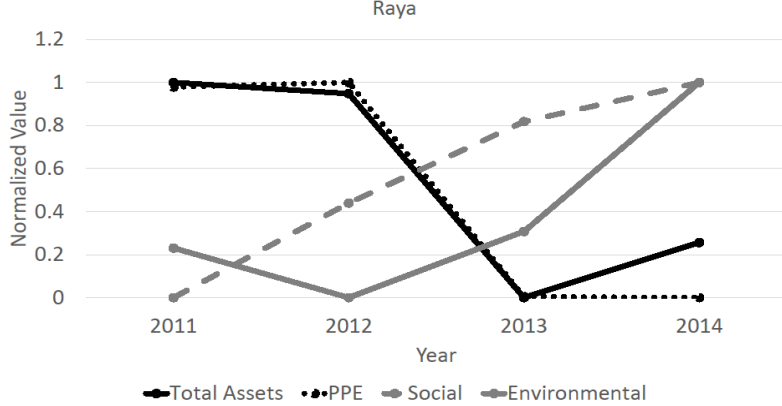

(b) Raya

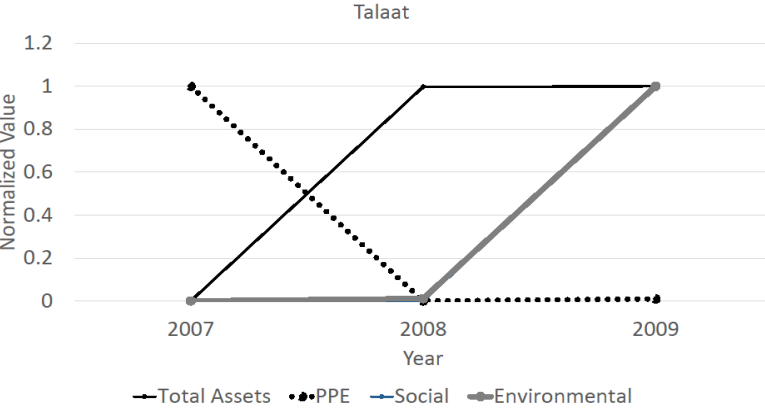

(c) Talaat Mostafa

Figure 1. (TL \& OE and PPE) and (Social and Environmental) Correlation of Toursims, Raya and Talaat Mostafa carried on six firms that generate social responsibility reports and listed on the Egyptian Stock Exchange. Using a GRI and ISO 26000 index, several variables have been examined (EPS, total assets, PPE, operating income, ROA and ROE). The content analysis method was used in this study to calculate CSR score to each dimension in the CSR report for the years 2007 to 2014 . This study shows that the financial performance represented by EPS is proportional with the Economical dimension in the CSR report, while the firm's size (represented by total assets and Property, Plant and Equipment) is proportional with Social and Environmental dimension in the CSR report. Finally, we found that other variables (i.e., ROE, ROA and operating income) do not affect CSR disclosure in Egypt. These findings show that financial performances for Egyptian firms play important role in enhancing CSR disclosure. Bigger firms tend to disclose more CSR compared to small ones especially the environmental and social dimension. Companies achieving high profits are keen to show their customers their economic strength. The contribution here lies in the quantitative proof of this fact. Also, the breakdown of the CSR report into 3 different dimensions according to the text analysis is considered an addition in detecting the correlation between both CSR and CFP.

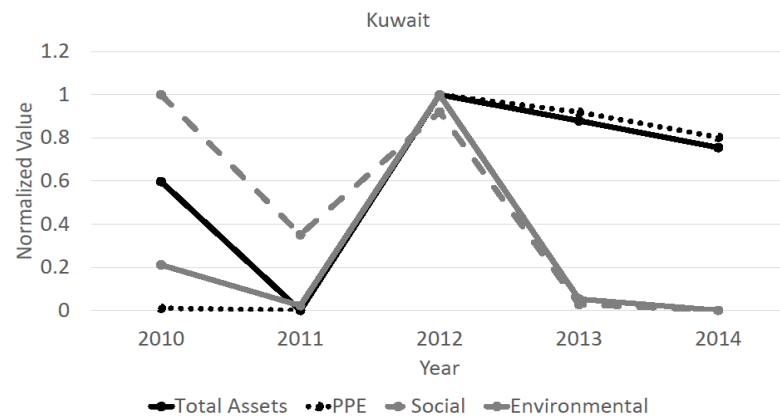

(a) Kuwait

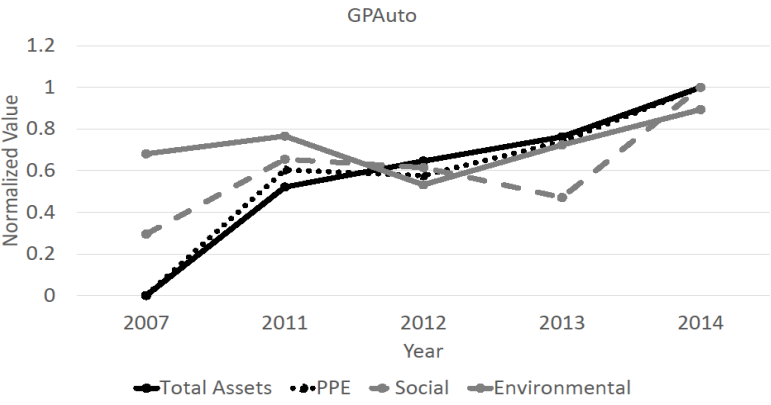

(b) GPAuto

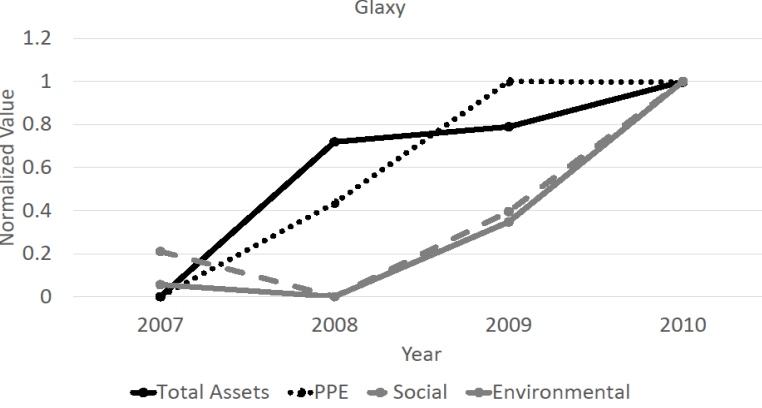

(c) GALAXY

Figure 2. (TL \& OE and PPE) and (Social and Environmental) Correlation of Kuwait, GP Auto and Glaxy 


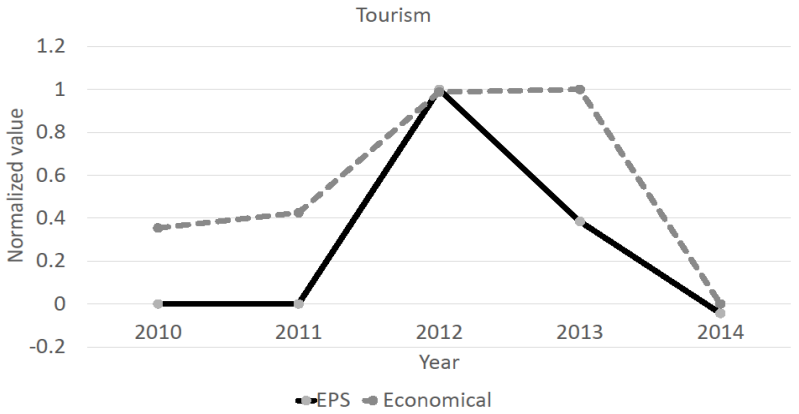

(a) Toursims

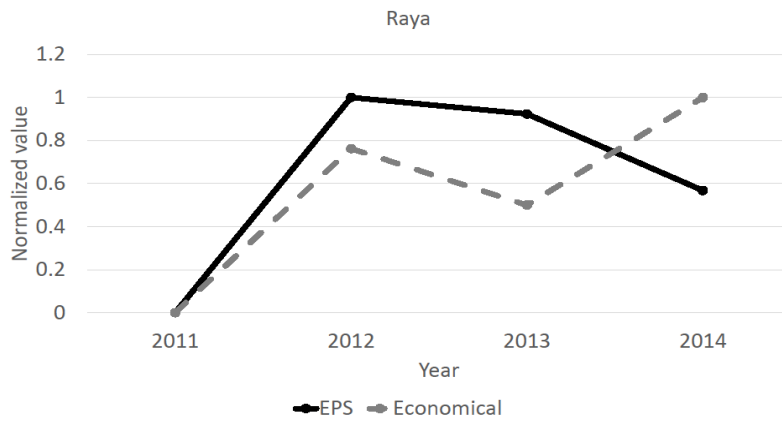

(b) Raya

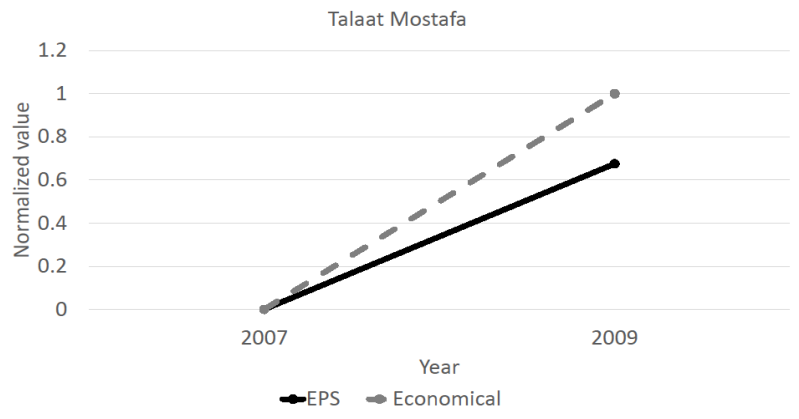

(c) Talaat Mostafa

Figure 3. EPS and Economical Correlation of Toursims, Raya and Talaat Mostafa

\section{REFERENCES}

[1] Karagiorgos, T. (2010). Corporate Social Responsibility and Financial Performance: An Empirical Analysis on Greek Companies.European Research Studies. Volume XIII. Issue (4).

[2] KPMG International (2013), The KPMG Survey of Corporate Responsibility Reporting 2013.

[3] Oh, W. and Park,S. (2015), The Relationship Between Corporate Social Responsibility and Corporate Financial Performance in

[4] Korea, Emerging Markets Finance and Trade 51(3), 2015.

[5] OZÇELIK, F., OZTURK, B. and GURSAKAL, S.(2014), Investigating the relationship between corporate social responsibility and financial performance in turkey, Atatürk Üniversitesi İktisadi ve İdari Bilimler Dergisi, Cilt, 28(3).

[6] Holme, L. and R. Watts, 1999. Making good buisness sense, the world council for sustainable development, Geneva.

[7] Griffin J.J and J. F. Mahom, 1997, The corporate social performance and corporate financial performance debate: twenty-five years of incomparable research. Buisness society, 36(1), 5-31.

[8] Brammer, S.; C. Brooks; and S. Pavelin. 2005. "Corporate Social Performance and Stock Returns." Financial Management 35, no. 3: 97-116 https://doi.org/10.1111/j.1755-053X.2006.tb00149.x

[9] Lopez, M.V.; A. Garcia; and L. Rodriguez. 2007. "Sustainable Development and Corporate Performance: A Study Based on the Dow Jones Sustainability Index." Journal of Business Ethics 75, no. 3: 285-300. https://doi.org/10.1007/s10551-006-9253-8

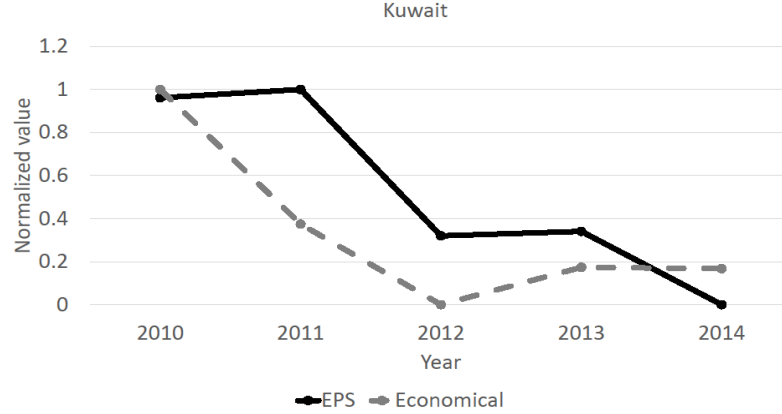

(a) Kuwait

GP Auto

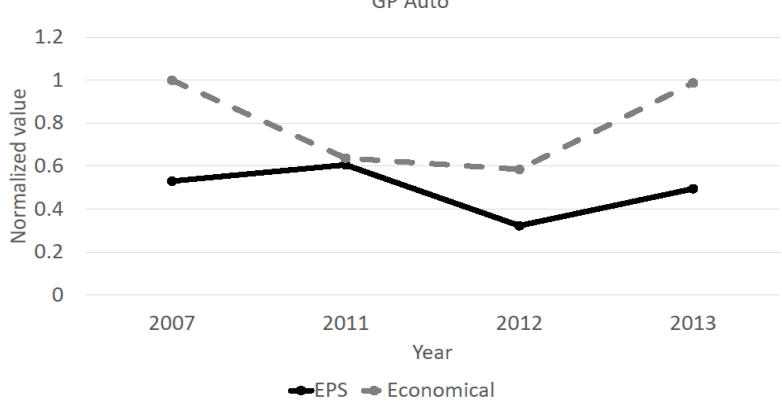

(b) GPAuto

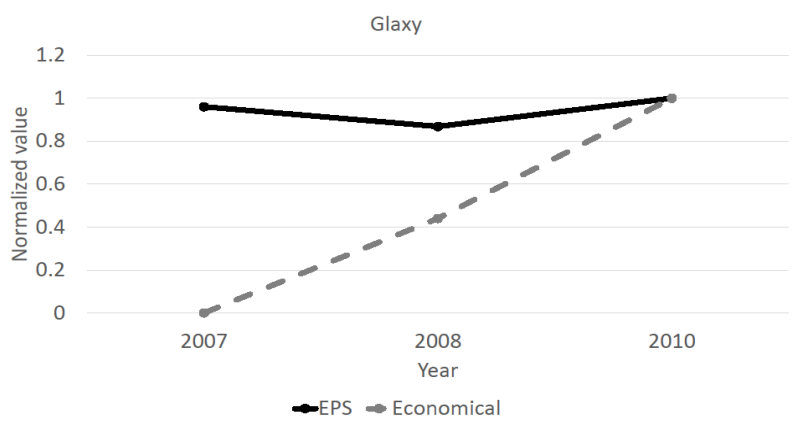

(c) GALAXY

Figure 4. EPS and Economical Correlation of Kuwait, GP Auto and Galaxy

[10] Jalal(2009),"Kesalahpahaman Seputar Tanggung Jawab Sosial Perusahaan". http://www.csrindonesia.com/data/articles/20090525 112318-a.pdf (accessed 26 May 2013)

[11] Branco, M. C., and Rodrigues, L. L. (2007), "Positioning Stakeholder Theory within The Debate on Corporate Social Responsibility", Journal of Business Ethics and Organization Studies, Vol. 12 No. 1 , pp. 5 - 15.

[12] Burhan, A. H., and Rahmanti, W. (2012). "The Impact of Sustainability Reporting on Company Performance", Journal of Economics, Business, and Accountancy Ventura, 15(2), pp. 257-272. https://doi.org/10.14414/jebav.v15i2.79

[13] Santoso,A. and Feliana,Y.(2014), The Association Between Corporate Social Responsibility And Corporate Financial Performance, Issues in Social and Environmental Accounting, 8(2).

[14] Beurden, P., I\& Gossling, T. (2008). The worth of values - a literature review on the relation between corporate social and financial performance. Journal of Business Ethics, 82, 407-424. https://doi.org/10.1007/s10551-008-9894-x

[15] Cordeiro,J. and Tewari, M.(2015), Firm Characteristics, Industry Context, and Investor Reactions to Environmental CSR: A Stakeholder Theory Approach, Journal of Business Ethics, 130(4). https://doi.org/10.1007/s10551-014-2115-x

[16] Wu, M.: 2006. Corporate Social Performance, Corporate Financial Performance, and Firm Size: A Meta-Analysis. Journal of American Academy of Business 8(1), 163-171.

[17] Rockmore,B. and Jones,F.(1996), "Business Investment Strategy and Firm Performance: A Comparative Examination of Account- 
ing and Market-Based Measures", Managerial Finance, 22(8). https://doi.org/10.1108/eb018576

[18] Hanafi, R. (2006). An exploration of corporate social and environmental disclosure in Egypt and the UK: a comparative study, $\mathrm{PhD}$ thesis, Glasgow University, UK.

[19] Chiong, Paul T. N. (2010), An Examination of Corporate Sustainability Disclosure Level and Its Impact on Financial Performance, Doctor of Philosophy Thesis, Multimedia University, Malaysia.

[20] Carroll, A. B. (1991): The Pyramid of Corporate Social Responsibility: Toward the Moral Management of Organizational Stakeholders, Business Horizons, 34, pp. 39-48. https://doi.org/10.1016/ 0007-6813(91)90005-G

[21] Vitezić, N., Vuko, T. and Mörec, B. (2012), "Does Financial Performance Have an Impact on Corporate Sustainability and CSR Disclosure - A Case of Croatian Companies", Journal of Business Management, pp. 40-47.

[22] Song, C., and W. Oh. 2015. "Determinants of Innovation in Energy Intensive Industry and Implications for Energy Policy.” Energy Policy 81, pp.122-130. https://doi.org/10.1016/j.enpol.2015. $\underline{02.022}$

[23] Oh,W. and Park,S. (2015), The Relationship Between Corporate Social Responsibility and Corporate Financial Performance in Korea, Emerging Markets Finance $\backslash \&$ Trade, 51, pp.85-94.

[24] Pieter van Beurden, Tobias Go"ssling, The Worth of Values - A Literature Review on the Relation Between Corporate Social and Financial Performance. Journal of Business Ethics (2008) 82:407424 https://doi.org/10.1007/s10551-008-9894-x

[25] Maria-Gaia Soana, 2011. The Relationship Between Corporate Social Performance and Corporate Financial Performance in the Banking Sector, Journal of Business Ethics 104: 133-148. https://doi.org/10.1007/s10551-011-0894-x

[26] Milne, M J and Adler, R W. (1999), "Exploring the Reliability of Social and Environmental Disclosures Content Analysis", Accounting, Auditing $\backslash \&$ Accountability Journal, Vol. 12, No 2, pp. 237-256. https://doi.org/10.1108/09513579910270138

[27] Neu, D., Warsame, H. and Pedwell, K. (1998), Managing public impressions: environmental disclosures in annual reports, Journal of Accounting, Organizations and Society, Vol. 23 No. 3, pp. $265-$ 82. https://doi.org/10.1016/S0361-3682(97)00008-1

[28] Vourvachis, Petros (2007) On the use of content analysis (CA) in corporate social reporting (CSR): revisiting the debate on the units of analysis and the ways to define them. In: British Accounting Association Annual Conference 2007; 3-5 April 2007, Egham, England.

[29] Jo, H. and Harjoto, M.a. (2012), 'the causal effect of corporate governance on corporate social responsibility', Journal of Business Ethics, 106, https://doi.org/10.1007/s10551-011-1052-1

[30] Abduallah, A. (2003). 'Accounting voluntary disclosure with empirical study to the demand factor in the Egyptian environment'. scientific journal of commerce and finance, faculty of commerce, university of Tanta, (1):250-307.

[31] AlKhial, T. A.(2009). 'Voluntary disclosure and its role in rationalize the investment decisions in Saudi capital market (field study) '. Scientific journal of economic and commerce, faculty of commerce, Ain Shams University, (3):105-152.

[32] Hussainey,K., Elsayed,M. and AbdelRazik ,M. (2011), Factor actors affecting corporate social responsibility disclosure in Egypt, Corporate Ownership and Control, Vol. 8, no. 4, 432 - 443.

[33] Ambec, S., and P. Lanoie (2008), Does It Pay to be Green? A Systematic Overview, Academy of Management Perspectives 22, 45-62. https://doi.org/10.5465/AMP.2008.35590353

[34] Barnett, M. L., I\& Salomon, R. M. (2006). Beyond dichotomy: The curvilinear relationship between social responsibility and financial performance. Strategic Management Journal, 27, 11011122. https://doi.org/10.1002/smj.557

[35] Servaes, H., $\ \&$ Tamayo, A. (2013). The impact of corporate social responsibility on firm value: The role of customer awareness. Management Science, 59(5), pp 1045-1061 https://doi.org/10.1287/mnsc. 1120.1630

[36] Perrini, F., Russo, A., Tencati, A., Vurro, C., 2011. Deconstructing the relationship between corporate social and financial performance. J. Bus. Ethics 102 (1 Supplement), 59---76.

[37] Endrikat, J., Guenther, E., \\& Hoppe, H. (2014). Making sense of conflicting empirical findings: A meta-analytic review of the relationship between corporate environmental and financial perfor- mance. European Management Journal. https://doi.org/10.1016/ j.emj.2013.12.004

[38] Bhattacharya, C. B., Korschun, D., \\& Sen, S. (2009). Strengthening stakeholder- company relationships through mutually beneficial corporate social responsibility initiatives.

[39] Orlitzky, M., Schmidt, F. L., I\& Rynes, S. L. (2003). Gorporate social and financial performance: A metaanalysis. Organization Studies, 24(3], 403-441. https://doi.org/10.1177/0170840603 $\underline{024003910}$

[40] McWilHams, A., Siegel, D. S., I\& Wright, P. M. (2006). Gorporate social responsibility: Strategic implications. Journal of Management Studies, 43, 1-18. https://doi.org/10.1111/j.14676486.2006.00580.x

[41] Dumitrescu, D., Simionescu, L. (2014). Should developing countries adopt corporate social responsibility? Empirical evidence from Romania. Journal of Economic Computation and Economic Cybernetics Studies and Research, 48(2): 19-36;

[42] Hassan,T. and Dr. Melegy,M.(2014), Economic consequences of corporate voluntary disclosure: Evidences from Egyptian listed companies, journal of Economics and Commerce, volume 1.

[43] Barnett, M. L. (2007). Stakeholder influence capacity and the variability of financial returns to corporate social responsibility. Academy of Management Review, 32(3), 794-816. https://doi.org/10.5465/AMR.2007.25275520

[44] Lee, M.-D. P. (2008). A review of the theories of corporate social responsibility: Its evolutionary path and the road ahead. International Journal of Management Reviews, 10(1), 53-73. https://doi.org/10.1111/j.1468-2370.2007.00226.x

[45] Santoso,A. and Feliana,Y. (2014), The Association Between Corporate Social Responsibility And Corporate Financial Performance, Issues in Social and Environmental Accounting, Vol. 8, No. 2, Pp. 82-103.

[46] Parket, I. R. and Eilbirt, H. (1975). Social responsibility: the underlying factor, Business Horizons, Vol. 18 No. 4, pp. 5-10. https://doi.org/10.1016/0007-6813(75)90019-1

[47] Scherer, A. G., \\& Palazzo, G. (2011). The new political role of business in a globalized world: A review of a new perspective on CSR and its implications for the firm, governance, and democracy. Journal of Management Studies, 48(4), 899-931. https://doi.org/10.1111/j.1467-6486.2010.00950.x

[48] Santoso,A. and Feliana, Y.( 2014), The Association Between Corporate Social Responsibility And Corporate Financial Performance, Vol. 8, No. 2, Pp. 82-103.

[49] Hassan, O.A.G.; Romilly, P.; Giorgioni, G.; Power, D., (2009). 'The value relevance of disclosure: Evidence from the emerging capital market of Egypt'. The International Journal of Accounting, 44: 79-102. https://doi.org/10.1016/j.intacc.2008.12.005

[50] Fauzi, H., Mahoney, L. S. and Rahman, A. A. (2007), "The Link between Corporate Social Performance and Financial Performance: Evidence from Indonesian Companies", Issues in Social and Environmental Accounting, 1 (1), pp. 149-159. https://doi.org/10.22164/isea.v1i1.12

[51] Aras, G., Aybars, A. and Kutlu, Ö. (2010), "Managing Corporate Performance: Investigating the Relationship Between Corporate Social Responsibility and Financial Performance in Emerging Markets", International Journal of Productivity and Performance Management, 59 (3), pp. 229-254. https://doi.org/10.1108/1741 0401011023573

[52] Nilipour, A. and Nilipour, A. (2012), "Survey of the Association between Financial Performance and Corporate Sustainability Performance (Case Study: Cement Companies Accepted at Tehran Stock Exchange)", Interdisciplinary Journal of Contemporary Research in Business, 3 (9), pp. 1084-1092.

[53] Ducassy,I.(2013), Does Corporate Social Responsibility Pay Off in Times of Crisis? An Alternate Perspective on the Relationship between Financial and Corporate Social Performance, Corporate Social Responsibility and Environmental Management, 20, 157167. https://doi.org/10.1002/csr.1282

[54] Neimark, M.K. (1992), The Hidden Dimensions of Annual Reports: Sixty Years of Social Conflict atGeneral Motors, Markus Wiener Publishing, New York, NY.

[55] http://www.egx.com.eg/English/homepage.aspx

[56] Web Site $\{$ http://responsiblefuture.in/\}

[57] Web Site \{http://www.csrwire.com/blog/posts/1485-evaluatingindias-top-companies-for-csr-2014\} 


\section{AUTHORS}

Wafaa Salah is with the Faculty of Business Administration, The British University in Egypt (BUE), Cairo, Egypt (wafaa.salah@bue.edu.eg).

Mostafa A. Salama is with the Faculty of Informatics and Computer Science, The British University in Egypt (BUE), Cairo, Egypt (mostafa.salama@gmail.com).

Submitted 19 November 2016. Published as resubmitted by the authors 23 December 2016. 